\title{
Symbole w filmie $W$ imię... Małgorzaty Szumowskiej w perspektywie interpretacji kerygmatycznej
}

Interpretacja kerygmatyczna wpisuje się w egzystencjalny i hermeneutyczny model czytania kultury i jest zjawiskiem stosunkowo nowym - dość solidnie zakorzenionym w literaturoznawstwie, nieobudowanym jednak teoretycznie w historii odbioru filmu. Artykuł jest próbą zastosowania pewnych mechanizmów kerygmatycznej interpretacji dzieła literackiego w filmie jako tekście kultury. Punkt wyjścia stanowi książka Adama Regiewicza Kino a kultura $w$ świetle antropologii współczesnej. Próba interpretacji kerygmatycznej (Lublin 2011), która jako jedyna w całości poświęcona jest przeniesieniu literackiej metody interpretacji kerygmatycznej do odbioru filmu. W tym ujęciu kerygmatyczna metoda interpretacji dzieła filmowego (paralelnie do literackiej) polega na zderzeniu go z biblijnym kerygmatem $\mathrm{w}$ celu znalezienia występujących między nimi powiązań i napięć. W perspektywie powyższych założeń $W$ imię... Małgorzaty Szumowskiej traktuję jako pewnego rodzaju lustro, w którym odbija się stosunek bohaterów do przepowiadania o miłości Boga do człowieka. Obraz Szumowskiej został nagrodzony Srebrnymi Lwami w Gdyni, nagrodą za najlepszą reżyserię, nagrodą dla Andrzeja Chyry najlepszego aktora, otrzymał także Teddy Awards na festiwalu w Berlinie, wreszcie nominację do Europejskiej Nagrody Filmowej, co czyni go dziełem godnym zainteresowania. Tadeusz Sobolewski napisał nawet, że $W$ imię... daje przedsmak „własnej religii kina: Szumowska stawia niepokojące przeklęte pytania. To ją wyróżnia w polskim kinie, które jest na ogół ilustracją z góry 
wiadomych tez. Jej filmy są przesiąknięte dwuznacznością, to właśnie nadaje im wymiar uniwersalny"'.

W części pierwszej artykułu przedstawiona została propozycja kerygmatycznej interpretacji $W$ imię... poprzedzona uwagami o rozległości terminu „kerygmat" oraz informacjami o rozwoju kerygmatycznej metody interpretacji, część druga natomiast poświęcona jest ważniejszym symbolom filmowym.

\section{Kerygmat w interpretacji tekstów kultury}

„Kerygmat” jest pojęciem wieloznacznym, bo wykorzystywanym nie tylko w głoszeniu prawd teologicznych, ale także choćby w badaniach literaturoznawczych. Słowo pochodzi od greckich kerygma, keryssein i oznacza głoszenie, przepowiadanie, prorokowanie. Biblijnymi źródłami kerygmatu są przepowiadający nadchodzące królestwo Boże Chrystus i apostołowie głoszący nowinę o zbawieniu, które dokonało się w postaci Jezusa, a także może się dokonać w każdym, kto w niego uwierzy. Ta łaska następuje jako dar ofiarowany grzesznikom i nie jest dziełem człowieka tylko darmowej, niezasłużonej łaski Boga. Kerygmat wiąże się z afirmowaniem tej prawdy i przekonywaniem o jej ciągłej aktualności. Kerygmatyczny charakter mów w Dziejach Apostolskich podkreśla dwie rzeczywistości: pierwsza z nich to rzeczywistość grzechu, pogrążanie się w kenozie, druga to przekonanie o tym, że miłość Boga przekracza rozmiary naszych niedoskonałości i że, jeśli zaufamy Bogu, będziemy zbawieni. Już w tym miejscu warto zauważyć pewną dwoistość kerygmatu, która będzie ważnym punktem odniesienia dla próby kerygmatycznej interpretacji filmu W imię... - jako zderzenie obrazu kondycji człowieka z obrazem miłości Boga.

Interpretacja kerygmatyczna w odbiorze dzieł sztuki pojawiła się jako konsekwencja hermeneutycznego modelu czytania literatury. Thomas Eliot pisał, iż „krytykę literatury należy uzupełnić z określonego stanowiska etycznego i teologicznego"2. Choć kerygmatyczna interpretacja literatury w perspektywie tradycji i badań literackich jest czymś stosunkowo nowym, to metoda związana $\mathrm{z}$ hermeneutycznym sposobem czytania tekstu znalazła już swoich zwolenników (m.in. Zofia Zarębianka, Ryszard Przybylski). Trzeba jednak wyraźnie zaznaczyć, iż nie jest bardzo rozpowszechniona. Propozycję odczytywania

Zob. T. Sobolewski, Trzy kropki, utrata orientacji, http://wyborcza.pl/piatekekstra/1,130894, 13365730,Trzy_kropki_utrata_orientacji.html, 10.11.2015.

2 T. S. Eliot, Religia i literatura, [w:] Szkice literackie, red. W. Chwalewik, Warszawa 1963, s. 106. 
literatury z punktu widzenia kerygmatu zaproponował nieżyjący już profesor Marian Maciejewski ${ }^{3}$. W literaturoznawstwie to swoiste przepuszczenie dzieła dodatkowo w stosunku do standardowych procedur przez pryzmat prawd wiary, pozwalające na odkrycie usytuowania tekstu wobec słowa Bożego po to, by sprawdzić występujące między nimi powiązania i napięcia ${ }^{4}$. W kształtowaniu się owej metody czytania ścierają się dwie koncepcje: pierwsza - Ryszarda Przybylskiego - traktuje samą literaturę jako swoiste przepowiadanie, głoszenie, obwieszczenie, druga - Mariana Maciejewskiego - każe interpretować teksty z punktu widzenia kerygmatu apostolskiego.

O ile jednak w literaturze pozostaje to już zjawiskiem stosunkowo opracowanym, o tyle przeniesienie kerygmatycznej interpretacji literatury na próby odczytania w podobny sposób filmu pojawiło się dopiero w ostatnich kilku latach. Jak pisał Jarosław Borowski: „pojęcie kerygmatu jest obce współczesnej

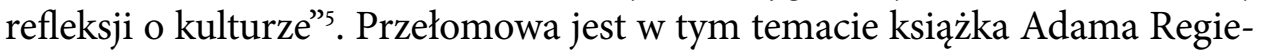
wicza Kino a kultura. W świecie antropologii współczesnej. Próba interpretacji kerygmatycznej (Lublin 2011), w której autor proponuje metodę odczytania filmu w perspektywie kerygmatu, który staje się punktem odniesienia w interpretacji filmowego tekstu kultury.

Regiewicz zauważa, że sztuka filmowa jako forma działalności człowieka jest dla współczesnego społeczeństwa, zanurzonego w kulturze popularnej, zmedializowanej i zaudiowizualizowanej, powszechnie dostępnym „pokarmem duchowym". Tym samym odpowiada ona pierwotnej potrzebie zaspokojenia potrzeb religijnych jednostki, która szuka w niej odpowiedzi na elementarne pytania o charakterze uniwersalnym, a zarazem teologicznym. Każdy z filmów zapisujących obraz ludzkiej kondycji można uważać za refleksję o charakterze egzystencjalnym, a co za tym idzie - każde dzieło filmowe jest więc przekazem na temat sensu życia: jest jakimś kawałkiem prawdy, który składa się na swoistą układankę - mozaikę rzeczywistości, jest swoistą konfrontacją z apostolskim kerygmatem.

Warto w tym miejscu zauważyć, że według Regiewicza nie tyle kerygmatyczna jest sama rzeczywistość filmowa, ile kerygmatyczność jest wartością

3 Zob. M. Maciejewski, Literatura w świetle kerygmatu, [w:] M. Maciejewski, „Ażeby ciało powróciło w słowo". Próba kerygmatycznej interpretacji literatury, Lublin 1991.

${ }_{4}$ Por. I. Piekarski, Interpretacja kerygmatyczna a tradycje i perspektywy badań literackich, [w:] Interpretacja kerygmatyczna. Doświadczenia - rewizje - perspektywy, red. J. Borowski, E. Fiała, I. Piekarski, Lublin 2014, s. 25.

5 J. Borowski, Kerygmat w kulturze?, [w:] Interpretacja kerygmatyczna..., dz. cyt., s. 47. 
aksjologiczną, dzięki której można przekazy filmowe odczytywać w perspektywie historii zbawienia ${ }^{6}$. Chrześcijański kerygmat staje się w takim modelu lustrem, w którym można odbić dzieło filmowe. To odbicie dostarcza wielu informacji na temat współczesnej ludzkiej kondycji (nazywane bywa kerygmatem negatywnym czy „katechezą świata”) i ukazuje Boży porządek, z którym człowiek się konfrontuje (nazywany kerygmatem pozytywnym). Powyższa uwaga metodologiczna jest istotna, ponieważ pozwala włączyć w obszar zainteresowania „badacza kerygmatycznego” filmy inne niż te należące do klasycznie definiowanego kina biblijnego ${ }^{7}$.

\section{W imię... - próba interpretacji kerygmatycznej}

Jeśli przyjrzymy się kerygmatowi, można jego treść podzielić na kilka części, które odpowiadają prawdom wiary chrześcijańskiej: miłość Boga; rzeczywistość grzechu; odkupienie w Chrystusie ukrzyżowanym, pogrzebanym i zmartwychwstałym; konieczność przyjęcia przez wiarę Chrystusa jako osobistego Pana i Zbawiciela; posłannictwo Ducha Świętego; tajemnica Kościoła - wspólnoty zbawionych. $W$ imię... Szumowskiej odbija te prawdy i inicjuje wśród nich rozmaite pytania.

Pytania o miłość Boga najdobitniej zostają pokazane w dwóch scenach. Pierwsza to scena płomiennego kazania księdza Adama, który mówi: „W samym środku naszej istoty jest punkt, niepokalany żadnym grzechem, punkt nicości należący wyłącznie do Boga, z którego dysponuje on naszym życiem, jest on w każdym z nas, [...] bo ta cząstka Boga jest w każdym z nas, [...] w każdym z nas jest ta iskra świętości”. Inna to choćby intymna scena modlitwy księdza Adama czy też sytuacja sportretowania pogrzebu młodego samobójcy Gaja.

Rzeczywistość grzechu i odkupienie w Chrystusie są podkreślane w filmie nieustannie. Już podczas wspomnianego wyżej kazania ksiądz Adam mówi: „Nigdy nie należałem do oazy. Do kościoła zacząłem chodzić w wieku 21 lat, bo pewnej nocy, kiedy byłem sam, nagle poczułem, że jest ze mną w pokoju mój rok wcześniej zmarły ojciec, że jest razem ze mną; było to bardzo mocne, bardzo konkretne odczucie, i w jednym momencie, w jednym błysku zobaczyłem całe zepsucie mojej duszy i zapragnąłem jak najprędzej wydostać się

A. Regiewicz, Kino a kultura w świecie antropologii współczesnej. Próba interpretacji kerygmatycznej, Lublin 2011, s. 6.

Por. M. Lis, Elementy biblijne w filmach niebiblijnych, [w:] Ukryta religijność kina, red. M. Lis, Opole 2002, s. 79. 
z tego więzienia [...]”. Świadomość grzeszności bohaterów podkreślona zostaje w przejmującej scenie spowiedzi, która dzieje się „na świeżym powietrzu”, pewnie przy murach kościoła, czy też niespodziewanej dla widza spowiedzi Michała, który po wizycie u biskupa i „donosie” na księdza Adama, zapewne pełen wyrzutów sumienia, zatrzymuje kapłana podczas joggingu, prosząc o sakrament pokuty. Mamy też swoistą „czatową spowiedź” księdza Adama przed własną siostrą, której dość bezpretensjonalnie wyznaje: „Jestem pedałem”.

W filmie widzimy także refleksję o tajemnicy Kościoła i roli Ducha Świętego. Podczas pogrzebu młodego samobójcy ksiądz Adam mówi: „Nie wiemy, dlaczego tak się stało, nie rozumiemy dlaczego, ale może wcale nie mamy rozumieć”. Wymienione wyżej słowa z kazania: „Do kościoła zacząłem chodzić w wieku 21 lat, bo pewnej nocy, kiedy byłem sam, nagle poczułem, że jest ze mną w pokoju mój rok wcześniej zmarły ojciec, że jest razem ze mną; było to bardzo mocne, bardzo konkretne odczucie, i w jednym momencie, w jednym błysku zobaczyłem całe zepsucie mojej duszy" - także konfrontują widza z pewnego rodzaju tajemnicą Kościoła i Ducha Świętego. Widzimy ją również w przejmującej opisywanej już wcześniej procesji Bożego Ciała.

W książce Adama Regiewicza Poza horyzontem. Eseje o sztuce czytania (Kraków 2015) autor rozszerza kerygmatyczny model czytania Dekalogu o jego związek z dziełem filmowym. Regiewicz przypomina, że prawo Tory zostało nadane przez Dziesięć Bożych Oświadczeń mających dawać życie. Gdy człowiek kształtuje swoje życie w oparciu o ten kodeks, jego świat funkcjonuje prawidłowo; gdy odwraca się od Dekalogu, rzeczywistość rozsypuje się na kawałki. Prawo Dekalogu jest więc lustrem, w którym człowiek nieustannie może się przeglądać, tak samo kino, „podobnie jak doświadczenie religijne, ma na celu przekazanie prawdy o nas samych, a ta objawia się przez konfrontowanie naszych konstrukcji mentalnych, wyobrażeń, projekcji z wydarzeniami przychodzącymi spoza naszego porządku - wywołanymi przez Boga, w tym przez kino"8. Każde dojrzałe dzieło filmowe, zdaniem autora, odnosi się do pytań egzystencjalnych, które mają początek w doświadczeniu religijnym - biblijnym ${ }^{9}$.

Życie bohaterów $W$ imię... to także ciągła konfrontacja z prawdami ewangelicznymi i przykazaniami Bożymi: Ewa, uwodząca księdza Adama, konfrontuje się z przykazaniem: „Nie cudzołóż”, Gaju (popełniający samobójstwo) z „Nie zabijaj”, Michał (donoszący biskupowi o rzekomych nieprawidłowych

\footnotetext{
A. Regiewicz, Kerygmatyczne czytanie Dekalogu, [w:] A. Regiewicz, Poza horyzontem. Eseje o sztuce czytania, Kraków 2015, s. 157.

9 A. Regiewicz, Kerygmatyczne czytanie Dekalogu, dz. cyt., s. 158.
} 
zachowaniach Adama) - z „Nie mów fałszywego świadectwa przeciw bliźniemu swemu". Wreszcie ksiądz Adam jako bohater centralny odbija się w lustrze najczęściej i najbardziej intensywnie. W przykazaniu „Nie będziesz miał bogów cudzych przede mną" widzimy pytanie o miejsce alkoholu w życiu kapłana, „Nie cudzołóż” czy „Nie pożądaj żony bliźniego swego” to prawdy odsłaniające dramat jego konfrontacji z własną seksualnością.

Kerygmat jako punt wyjścia do opisu rzeczywistości kulturowej „pozwala na dokonanie konstatacji na temat ścierania się w niej antropologii ludzkiej i Boskiej"10. Ta pierwsza to pokazanie w duchu antropocentryzmu potrzeb człowieka, który organizuje życie według swoich pragnień. Ta tendencja znajduje swoje odbicie w twórczości filmowej - pokazuje często współcześnie ludzką kondycję, ale i konfrontację z Bożym porządkiem. Jest ona podkreślana w filmie Szumowskiej wielokrotnie, najdobitniej przez młodych wychowanków poprawczaka: „Ale jak on oddał serce Bogu, to może nie myśli o ruchaniu [...] ale nie ma tak, że oddał serce i się nie rucha [...] ksiądz to ksiądz, ale ma taką potrzebę, jak każdy człowiek".

Jak pisze Regiewicz, współczesny film często przedstawia konsekwencje erozji duchowej, m.in. erotyzację, cielesność, idolatrię, materializm. Regiewicz taką strukturę obrazu świata nazywa „współczesną katechezą świata” ${ }^{11}$. Bez wątpienia odnajdziemy taki obraz w filmie Szumowskiej $W$ imię...

Erotyzacja jest w tej produkcji widoczna na kilku poziomach. Po pierwsze w samym głównym bohaterze - chociażby onanizujący się ksiądz. Mamy niemalże w finale filmu także scenę spełnienia seksualnego głównego bohatera - księdza - i Dyni. Po drugie w młodych ludziach - chłopak spowiadający się z tego, iż po imprezie „obciągnął drugiemu”. Widzimy stosunek seksualny dwóch młodych mężczyzn czy wreszcie uwodzącą księdza Ewę, która pręży się i wije półnaga przed nim, jak wąż przed biblijnym Adamem.

Kult ciała związany z motywami erotycznymi pojawia się u Szumowskiej także w różnych innych scenach i związany jest ze swoistą współczesną antropologią ciała, która każe traktować je jako miejsce objawiania się świata człowiekowi. Ciało staje się miejscem, w którym można odbić wiele procesów i zjawisk dzisiejszej kultury - wreszcie ciało służy orientacji w świecie i jest żywiołem urągającym porządkowi czy hierarchii ${ }^{12}$. Ciekawa jest na przykład scena pojedynku na rękę dwóch młodych chłopaków (ważne jest, że przegrywający

\footnotetext{
A. Regiewicz, Kino a kultura..., dz. cyt., s. 6.

A. Regiewicz, Kino a kultura..., dz. cyt., s. 6.

A. Regiewicz, Kino a kultura..., dz. cyt., s. 59.
} 
ten pojedynek popełnia samobójstwo), scena kąpieli nago Łukasza. Chłopcy są konsekwentnie portretowani w sytuacjach sprzyjających nagości (praca fizyczna, gra w piłkę, pływanie). Także półnagi ksiądz Adam w samych bokserkach upija się i tańczy z portretem papieża.

Materializm widzimy w zabawnej scenie rozmowy księdza Adama z młodzieżą: „Ksiądz to ma wszystko orginałki, bez kitu, [...] ksiądz ma oryginalne buty, zamszowe ładne spodnie, dzieci w Afryce nie mają co jeść, co pić..."; może także w przewrotnym, choć dość jednostronnym przedstawieniu wsi mazurskiej, naznaczonej biedą, która w filmie Szumowskiej podkreślana jest notorycznie - na przykład przez stroje młodych ludzi i kreację przestrzeni (sklep).

W tym wymiarze tak nieustanna i wielopoziomowa konfrontacja z kerygmatem jest w filmie Szumowskiej dowodem jej wpasowania się w zapotrzebowanie widza wieku XXI, który czeka na zaspokojenie lub obietnicę zaspokojenia przez kino odpowiednich przyjemności. Na te przyjemności składają się zdaniem amerykańskich badaczy: jedzenie i picie, seks, związki społeczne (szczególnie stan zakochania), sukces, używanie własnych zdolności (na przykład praca), sport, muzyka i alkohol' ${ }^{13}$.

Scenariusz filmu $W$ imię... i końcowy efekt produkcji doskonale mieszczą się w potrzebach widza-konsumenta, odbijając wszystkie potrzeby w kreacji postaci księdza - widzimy wiele scen jedzenia, picia, przygotowywania posiłków, obecna jest scena seksu kapłana w finale filmu. Widzimy stan zakochania jako motor akcji i tworzone więzi społeczne (przyjaźń z wychowankami, relacje z parafianami). Jesteśmy świadkami sukcesów (intensywna praca księdza w ośrodku wychowawczym), napotykamy na sport (u księdza Adama bieganie), słyszymy muzykę (scena tańca z portretem papieża i scena procesji Bożego Ciała) czy widzimy alkohol (nadużywanie go przez kapłana).

Edward Fiała zauważa, że można mówić współcześnie o swoistym modelu egzystencjalnym kerygmatu zawierającym trzy ważne elementy. Pierwszym z nich jest orędzie o Bożej miłości, drugi odsłania odbiorcę orędzia jako grzesznika, trzeci stanowi przyjęcie bądź odrzucenie przesłania kerygmatycznego, co skutkuje albo osobistym nawróceniem, albo pozostaniem w rzeczywistości grzechu. Autor zauważa, że kerygmat biblijny odsłania ontyczny (a więc głęboko zapisany w strukturze bytu ludzkiego) grzech człowieka, przedstawiając go często jako zniewolonego w kierunku zła mimo pragnień czynienia dobra. Takie usytuowanie odsłania jego dramat egzystencjalny, w którym widzimy

\footnotetext{
${ }^{13}$ A. Regiewicz, Kino a kultura..., dz. cyt., s. 37.
} 
nieustanne napięcie między prawem Bożym, a prawem grzechu. Skutkuje to figurą podmiotu, w którym zobrazowana zostaje walka pragnień ciała z pragnieniami Ducha ${ }^{14}$.

Bardzo interesująco w kontekście kerygmatu rysuje się filmowa rola księdza - bohatera pierwszoplanowego. Kapłan w filmie Szumowskiej jest postacią niejednoznaczną. Jak zauważa Tadeusz Sobolewski, ksiądz w filmie Szumowskiej „niczego nie udaje, nie ma księżowskiego głosu ani manier. Ksiądz, jakiego by się chciało - otwarty, rozumiejący ${ }^{\prime 15}$. Rzeczywiście, ks. Adam potrafi zatańczyć z kobietą, spowiada trudną młodzież podczas rozmowy na stojąco, nie boi się „łyknąć piwa” z chłopakami z poprawczaka. Wypełnia swoje kościelne obowiązki - głosi niebanalne kazania, odprawia pogrzeby, prowadzi procesję Bożego Ciała, modli się, czyta Biblię - pragnie czynić dobro. Ale Szumowska prowadzi nas także w świat pięknych, szerokich, skadrowanych w paletach błękitu ujęć natury, przypominających Powrót Zwiagincewa, w których odsłania się dramat bohatera - biegnącego przez las, a tak naprawdę uciekającego w pustkę, szukającego ciszy, Boga, Ducha? Mówi on w pewnym momencie: "Bieganie to też modlitwa” - może, ale dla księdza Adama nie tylko. To także ucieczka od „pragnień ciała”.

Tę „kerygmatyczną walkę ciała z Duchem” w filmie widzimy, gdy ksiądz Adam masturbuje się, ucieka $\mathrm{w}$ alkohol, tańczy pijany $\mathrm{z}$ portretem papieża, rano wstaje, uśmiecha się, wspiera rozmową młodych ludzi, głosi kazania rodem z mistrza Eckharta, pomaga chłopakom z poprawczaka podczas prac fizycznych. Pragnienie dobra także zostaje wyraźnie zaznaczone w filmie bohater walczy o swoją czystość (terapią są sport, muzyka, alkohol), chce się spowiadać. Jest miły, niewulgarny, charyzmatyczny, otwarty. Jako jedyny udziela pomocy dziewczynie podczas ataku padaczki - jak miłosierny samarytanin wieku xxi obmywa z krwi pobitego młodzieńca. Potrafi także radzić sobie w sytuacjach trudnych - odmawia seksu Ewie czy Adrianowi. Scenariusz filmu sprzyja oddaniu behawioralnego rysu tej postaci, zrealizowanej zresztą wybitnie przez Chyrę. Na uwagę w kreacji kapłana zasługuje inteligentny montaż, przez który Adama poznajemy uwięzionego „w jakiejś tajemnicy”, bez zbędnych przerysowań i z celowo naszpicowanymi dłużyznami z jednej strony pobudzającymi wyobraźnię widza, a z drugiej świetnie oddającymi dramat bohatera, który nie znajduje po prostu słów, by wyrazić, co czuje. Sam

14 Por. E. Fiała, Fenomen kerygmatu: Biblia - wiara - teologia, [w:] Interpretacja kerygmatyczna..., dz. cyt., s. 9-20.

${ }_{15}$ T. Sobolewski, Trzy kropki, utrata orientacji, dz. cyt. 
kapłan mało o sobie mówi - jedyny wyjątek to przejmująca scena „spowiedzi internetowej" przed własną siostrą, której pijany wyznaje wprost swoje uczucia: „Pójdę im i powiem [...] jestem chory, żeby mnie przestali w końcu, kurwa, przenosić, bo ja też się przyzwyczajam, i jest mi smutno".

Niejednoznaczność tej kreacji widzimy zwłaszcza w zakończeniu filmu; nie wiemy, czy bohater wybiera (zgodnie z egzystencjalnym modelem kerygmatu) nawrócenie, czy pozostanie w grzechu. Ksiądz ulega bowiem w końcówce filmu homoseksualnej miłości, ale nie porzuca swojego powołania. Słusznie pyta Tadeusz Sobolewski: „Czy tylko z powodu kamuflażu? Czy dlatego, że religia uwzniośla jego namiętność, bo inaczej w oczach ludzi byłby tylko «pedałem»? Czy z powodów głębszych - bo naprawdę chce służyć Chrystusowi?”"16. Odbija się w tym momencie filmu kolejny raz kerygmatyczne napięcie: napięcie między zniewoleniem w kierunku zła a pragnieniem czynienia dobra, podkreślone zresztą słowami samego bohatera: „Co dzień umieramy i rodzimy się na nowo. Nachodzi nas zwątpienie. To, co było kiedyś dla nas ważne, staje się miałkie, a to, co kochaliśmy, odrzuca nas. I ten cierpiący człowiek buntuje się, jego prawo. Walczy, ucieka. Amen".

\section{Symbole}

Semiotyka wiąże film i religię poprzez język symboli. Kino w swej strukturze posiada charakter znakowy, podobnie do religii wytwarzającej pewne modele rzeczywistości. Ricour czy Eliade uważają, że symbol (operowanie symbolem) jest dowodem na związek człowieka z sacrum. Właściwie więc symbol nadaje w jakimś sensie filmowi charakter religijny. Interpretacja filmu to zatem próba deszyfracji symbolu, obecnego jednocześnie w dwóch rzeczywistościach konkretnej (geograficzno-historycznej), którą w omawianym filmie stanowić mogą: mazurska wieś, parafia, Kościól, ksiądz, i nieokreślonej, często sakralnej - odnoszącej film do dylematów uniwersalnych. Ta druga płaszczyzna symbolu podkreślona została przez samą reżyserkę już w pierwotnej propozycji tytułu: Nowhere, czyli nigdzie, a także zaznaczana jest ciągle w świecie przedstawionym filmu - bohaterowie noszą koszulki $z$ angielskimi napisami (choćby słynna Coca-Cola), sklep nazywa się Market Niagara, w mieszkaniu księdza Adama widzimy flagę wolnego Tybetu nad łóżkiem, a na ścianach wiszą grafiki Eschera.

16 T. Sobolewski, Trzy kropki, utrata orientacji, dz. cyt. 
Symboliczna sakralność świata Szumowskiej budowana jest poprzez czynności rytualne (msza, kazanie, spowiedź, pogrzeb, procesja Bożego Ciała), ale także codzienne, które nabierają charakteru egzystencjalnego (bieganie staje się formą modlitwy, przytulenie czy spojrzenie wyrażają pragnienia, odczucia niematerialne: samotność, tęsknotę, ból). Warto także zwrócić uwagę na naturę, której rola podkreślana jest w filmie nieustannie: mazurska wieś - impresjonistyczne synestezyjne pejzaże, bezkresna przestrzeń lasu, czy ponury ciemny krajobraz podczas pogrzebu młodego samobójcy. Z jednej strony ma ona wymiar sakralny, unaocznia spotkanie z jakąś Tajemnicą i uruchamia wyobraźnię „wychodzącą poza widziany obraz”, z drugiej wyzwala autentyzm erotyczny i egzystencjalny bohaterów - jak u Iwaszkiewicza - pozwala wykrzyczeć prawdę o sobie i o własnej dzikości (doskonałym przykładem jest scena w polu kukurydzy) i jako jedyna jest świadkiem nagości - tej fizycznej i emocjonalnej.

Symbole w filmie Szumowskiej organizują się wokół dwóch pól filmu $W$ imię... to $\mathrm{z}$ jednej strony historia prywatna, mocno podkreślona przez scenariusz, zdjęcia czy sposób montażu, zaznaczona także charyzmatyczną grą Andrzeja Chyry. Ale choć Szumowska wielokrotnie podkreślała, iż jest to film o dobrym człowieku, który mierzy się z czymś silniejszym od niego, nie można nie wspomnieć o symbolach narzucających w jakimś sensie czytanie tego filmu „publicystycznie”, mimo wyraźnego sprzeciwu reżyserki, która kiedyś zaznaczyła: „Przyczepia mi się łatki prowokatorki, którą wcale nie jestem. Chciałam zrobić film o straszliwej tęsknocie za miłością [...]. Nie pójdę z nim do Sejmu, nie włączę się w żadną debatę"17.

Nachalna i momentami przerysowana (może kiczowata) jest w filmie Szumowskiej symbolika biblijna. Główny bohater to Adam, uwodząca go bohaterka to Ewa. Scena nauki pływania przypomina biblijny motyw chrztu, rozkrzyżowane ręce Łukasza nasuwają od razu analogię do Chrystusa. Portretowanie śpiącego księdza Adama przywołuje podobieństwo do obrazu Andrei Mantegny Opłakiwanie zmarłego Chrystusa, a scena posiłku księdza Adama i siedzących obok podopiecznych uruchamia analogię z ostatnią wieczerzą. Uwiarygadnia to zasadność odbioru tego filmu w perspektywie interpretacji kerygmatycznej.

$\mathrm{Z}$ drugiej strony trudno uciec od przyznania racji tym krytykom, którzy czytają film Szumowskiej jako aluzję do rzeczywistości Kościoła w Polsce.

${ }_{17}$ Cyt. za: T. Sobolewski, To piękno trzeba złamać, http://wyborcza.pl/piatekekstra/1,130894, 13365759,Szumowska_To_piekno_trzeba_zlamac.html?disableRedirects=true, 15.02.2016. 
Choć sama reżyserka protestuje, są w tym filmie przynajmniej cztery sceny, które czynią jej protest bezzasadnym. Pierwsza to poruszająca scena rozmowy księdza Adama ze sprzątaczką, kiedy chce on się wyspowiadać:

[wyłączenie odkurzacza]

- Tak?

- Przepraszam, czy można się wyspowiadać?

- Teraz nie można.

- Dlaczego?

- Jest sprzątanie.

- A gdzie jest ksiądz?

- Ksiądz jest zajęty.

[włączenie odkurzacza]

Druga scena to rozmowa Michała $\mathrm{z}$ biskupem, podczas której Michał informuje biskupa o nieprawidłowym zachowaniu księdza Adama; poprzedza ją najazd kamery (i jednocześnie oczu Michała) na napis (o, ironio): „Zachowaj milczenie. Pan jest blisko". Warto zwrócić uwagę na scenografię tego fragmentu: podczas rozmowy siedzi tylko biskup, zresztą za biurkiem jest tylko jedno krzesło, petent stoi. Ale ważniejsze są słowa biskupa: „Nie zamiatamy pod dywan, jak to się powszechnie mówi”, będące przecież niewątpliwie czytelną aluzją do oskarżeń pod adresem Kościoła w Polsce ze strony wielu środowisk o brak publicznego komentarza i rozwiązywanie spraw trudnych „w zaciszu kurii”. Czwarta już scena to bardzo dramatyczne wyznanie bohatera przed własną siostrą, które mogłoby być kulminacją rozpaczy prywatnej bohatera, braku siły, zwątpienia, gdyby nie jedno sformułowanie: „Nie jestem pedofilem, jestem pedałem", nasuwające analogię do konkretnego historycznego momentu Kościoła mierzącego się z problemami pedofilii wśród księży.

Są w filmie Szumowskiej sceny symboliczne niejednoznaczne, trudne do rozczytania, a przez to ciekawe. Pierwsza to wspomniana przeze mnie scena w polu kukurydzy. Odbywa się bezpośrednio po tym, jak ksiądz Adam uczy Dynię pływać. Nagle w drodze powrotnej Łukasz wyrzuca swoje ubrania i biegnie w pole kukurydzy. Po bezskutecznych nawoływaniach lekko zaniepokojony ksiądz Adam podąża za nim w poszukiwaniu. Po chwili słyszy odgłosy Łukasza, przypominające odgłosy małp. Zaczyna mówić podobnym językiem. Rozpoczyna się swoista rozmowa między mężczyznami. W tle mazurska przyroda, gra światła i cienia, wysokie kolby pozwalające na totalną autentyczność - w końcu nikt nie patrzy. Łodygi biją właściwie w „twarz” kamery, a więc 
w naszą twarz. Scena staje się coraz bardziej dynamiczna i intensywna - wręcz teatralna. W pewnym momencie zachowanie księdza Adama przypomina zachowanie goryla - jakby bohater chciał wykrzyczeć swoją dzikość i inność, tyle że nie przynosi to ulgi. Wiele w tej scenie autentyzmu, ale i rozpaczy, bo język okazuje się (może to komunikat reżyserki) niewystarczającym narzędziem, by wykrzyczeć prawdę o sobie. Ksiądz zdaje się swoją powściągliwością teatralną i umiarem ekspresji mówić: nigdzie nie ma miejsca na autentyczność. Człowiek nie jest tylko czystym elementem natury.

Druga scena dzieje się już po ekspozycji dramatu głównego bohatera, po tańcach z portretem papieża, po nieudanej próbie spowiedzi, kiedy ksiądz Adam odchodzi samotny i smutny spod krat konfesjonału. Adam i Dynia jadą samochodem. Ksiądz zatrzymuje auto. Scena jest statyczna. Wokół puste pola. Adam pochyla się i opiera głowę na ramieniu Dyni. Właściwie nic się nie dzieje, a dzieje się wszystko - poza obrazem. Widzimy dramat samotności człowieka. Nie księdza czy duchownego. Człowieka. Scena domknięta zostaje piosenką o tęsknocie Telly'ego Savalasa Some broken hearts never mend, w której słyszymy słowa: „Kilka złamanych serc - nigdy nieposkładanych, | Kilka wspomnień - niezakończonych"18.

Trzecia to przejmująca i długa scena procesji Bożego Ciała, połączona sekwencyjnie ze sceną tańca księdza Adama z portretem papieża przez piosenkę Band of Horses zespołu The Funeral, a poprzedzona przejmującym kadrem przedstawiającym siedzącego na podłodze, opartego o ścianę, samotnego człowieka. Nie widzimy jego twarzy, skryta jest za meblami. Podczas procesji dostrzegamy już kapłana - instytucję. Mazurska przyroda, krzyż, słońce, monstrancja, ksiądz Adam i wszyscy mieszkańcy - dobrzy, źli, niepełnosprawni, młodzi, starsi, dzieci. A w tle nie religijna pieśń, tylko ballada, w której słyszymy: „Przychodzę tylko, by Cię podtrzymać, | Przychodzę tylko, by pokazać, że się mylisz. | Poza tym: martwe liście, które leżą na trawniku, | Zanim umarły, posiadały swoje drzewa, które podtrzymywały ich nadzieję.| Przychodzę tylko, by się wykazać przed tobą, | Przychodzę tylko, by pokazać, że się mylisz, | I przy każdej okazji będę gotowy na pogrzeb”. Rytuał i prywatna modlitwa. Manifestacja wiary i zwątpienia zarazem. Światła i ciemności. Sacrum i profanum w człowieku i w świecie. Jak na grafikach Eschera.

Widać więc, że dzieło Szumowskiej jest, co trzeba wyraźnie zaznaczyć, kampowe - kolażowe, przesycone symboliką, pełne nawiązań i analogii, w jakimś wymiarze ironiczne, wyrażające dystans wobec świata, wreszcie używające

\footnotetext{
18 Tłumaczenie własne.
} 
świadomego kiczu czy przerysowań - tak przerysowane i sztuczne są chociażby pozy mężczyzn w wodzie, które w wyobraźni odsyłają od razu do dzieł Michała Anioła. Anna Mizerka w artykule Kamp po polskư podkreśla, że główną cechą kampowej twórczości jest „estetyczne przekroczenie”, wyrażające się przede wszystkim przez świadomą estetyzację, łączenie różnych sprzecznych wartości czy stylów. Przejawia się także wyraźnym wykorzystywaniem stereotypów do własnych celów oraz pochwałą wieloznaczności. Wszystkie te cechy odnajdziemy w filmie Małgorzaty Szumowskiej, co udowodniłem, analizując warstwę symboliczną filmu. Cechą kampowości jest także burzenie podziałów (np. na publiczne-prywatne, racjonalne-irracjonalne, polityczne-estetyczne, sakralne-obrazoburcze). To burzenie jest widoczne głównie w niejednoznacznej kreacji kapłana oraz zakończeniu W imię... Kamp w szczególności realizuje się tam, gdzie sięga zakres otwartości i tolerancyjności społeczeństwa - w filmie Szumowskiej zagadnieniami kampowymi stają się: ciało, pozycja w społeczeństwie, tożsamość seksualna, religia, Kościół.

\section{Wnioski}

Pożądane staje się prowadzenie badań w celu opracowania metodologicznych podstaw kerygmatycznej interpretacji filmu, która to metoda wydaje się ciekawą propozycją hermeneutycznej i semiotycznej strategii odbioru tekstu filmowego.

Kerygmatyczna interpretacja filmu Małgorzaty Szumowskiej W imię... pozwala potwierdzić tezę Zygmunta Baumana, iż kultura współczesna realizuje w jakimś zakresie strategię uwodzenia konsumenta i jest kulturą ciągle niezaspokojonego pragnienia. Film Szumowskiej, głosząc kerygmat negatywny, otwiera (zgodnie z założeniami teologicznymi kerygmatu) możliwość usłyszenia kerygmatu pozytywnego i może stać się impulsem do zmiany w perspektywie odziaływania film-widz. W tym sensie kerygmatyczność $W$ imię... jest dwupoziomowa - w świecie fabuły film staje się pewną miarą zachowań człowieka, jak w lustrze pokazuje destrukcję i niemożność wyzwolenia się z grzechu - w świecie oddziaływania na widza może być jednak ciekawą okazją do postawienia przed sobą lustra i objawienia prawdziwego siebie ${ }^{20}$.

19 A. Mizerka, Kamp po polsku, „Horyzonty Polonistyki” 10 (2003), s. 27-32.

${ }^{20} \mathrm{O}$ takich wymiarach kerygmatycznej interpretacji literatury pisze Ireneusz Piekarski - dzieła literackie, ukazując drogę „w dół” i człowieka „w cieniu śmierci”, otwierają możliwość usłyszenia 
Symbole religijne w filmie $W$ imię... Szumowskiej budują sceny o różnej jakości - służą z jednej strony ekspozycji dramatu prywatnego - określania własnej tożsamości, potknięć, nawróceń, walki, indywidualnych pytań o sens wiary, miłość Boga, bliskość z drugim człowiekiem, dobro, zło; z drugiej jednak strony wpisanie ich w konkretny kontekst każe zwrócić uwagę na instytucję Kościoła czy narodową polską tożsamość. Rację ma Tadeusz Sobolewski, który pisze, iż „jest w tym filmie smutek współczesnego Europejczyka, który nie może znaleźć ukojenia ani w tradycyjnej religii, ani w jej braku"21.

\section{ABSTRAKT}

Kerygmatyczna interpretacja filmu jest stosunkowo nowym modelem spojrzenia na obraz filmowy. Rozwija się od kilku lat w odniesieniu do funkcjonującego już od dawna modelu interpretacji w literaturze jako poszerzenie sztuki interpretacji o dyskurs teologiczny i religijny. Artykuł przybliża zasady interpretacji kerygmatycznej. Autor interpretuje w tym duchu film $W$ imię... Małgorzaty Szumowskiej, analizując jego symbolikę w kontekście aluzji fabularnych, literackich i malarskich.

$W$ imię... Małgorzaty Szumowskiej (2013) jest jednym z bardziej docenianych filmów ostatnich lat - otrzymał m.in. Srebrne Lwy w Gdyni, nagrodę za najlepszą reżyserię, nagrodę dla Andrzeja Chyry jako najlepszego aktora. Jednak premiera filmu wywołała wielkie emocje. Niektórzy nazwali go „antykościelnym”, ,jednostronnym”, „miałkim”, inni określili najciekawszym filmem festiwalu w Berlinie.

W artykule autor skupia się także na filmowej roli księdza, która wydaje się przełomem w portretowaniu księdza we współczesnym polskim kinie. Wnioski z interpretacji filmu pojawiają się w kontekście refleksji ogólnych dotyczących filmowych ról księdza w polskim kinie.

\section{SŁOWA KLUCzOWE}

ksiądz, symbol, kerygmat, interpretacja kerygmatyczna

kerygmatu pozytywnego i tym samym dają perspektywę nawrócenia. Por. I. Piekarski, Interpretacja kerygmatyczna a tradycje..., dz. cyt., s. 29.

\footnotetext{
${ }_{21} \quad$ T. Sobolewski, To piękno trzeba złamać, dz. cyt.
} 


\section{Abstract \\ The symbols in the movie titled $W$ imię... of Małgorzata Szumowska in the perspective of kerygmatic interpretation}

The kerygmatic interpretation of movies is a relatively new way of film interpretation. For the last few years it has been developing in association with the long-known interpretation of literature as a broadening of the art of interpretation by theological and religious discourse. The article explains the principles of kerygmatic interpretation. According to these rules, the author interprets Małgorzata Szumowska's film In the name of..., whilst analyzing the films symbolism in the context of plot, literary and art allusions.

In the name of... ( $W$ imię...), directed by Małgorzata Szumowska and released in 2013, has been one of the most acclaimed films of the past few years. It received, among others, Silver Lions in Gdynia, an award for the best directing and a best actor award for Andrzej Chyra, however the premiere caused much controversy. For some, the film was "anticlerical," "one-sided," "meager," whilst for others it was the most interesting film at the Berlin Festival.

In the article, the author also focuses on the role of the priest in the film, which seems to be a breakthrough in the portrayal of priests in modern Polish cinema. The conclusions stemming from the interpretation of the film are presented in the context of general thoughts concerning the roles of priests in Polish cinema.

\section{KEY WORDS}

priest, symbol, kerygma, kerygmatic interpretation

\section{BIBLIOGRAFIA}

Borowski J., Kerygmat w kulturze?, [w:] Interpretacja kerygmatyczna. Doświadczenia - rewizje - perspektywy, red. J. Borowski, E. Fiała, I. Piekarski, Lublin 2014.

Eliot T. S., Religia i literatura, [w:] Szkice literackie, red. W. Chwalewik, Warszawa 1963. Fiała E., Fenomen kerygmatu: Biblia - wiara - teologia, [w:] Interpretacja kerygmatyczna. Doświadczenia - rewizje - perspektywy, red. J. Borowski, E. Fiała, I. Piekarski, Lublin 2014.

Lis M., Elementy biblijne w filmach niebiblijnych, [w:] Ukryta religijność kina, red. M. Lis, Opole 2002.

Maciejewski M., Literatura w świetle kerygmatu, [w:] M. Maciejewski, „Ażeby ciało powróciło w słowo". Próba kerygmatycznej interpretacji literatury, Lublin 1991.

Mizerka A., Kamp po polsku, „Horyzonty Polonistyki” 10 (2003), s. 27-32. 
Piekarski I., Interpretacja kerygmatyczna a tradycje i perspektywy badań literackich, [w:] Interpretacja kerygmatyczna. Doświadczenia - rewizje - perspektywy, red. J. Borowski, E. Fiała, I. Piekarski, Lublin 2014.

Regiewicz A., Kino a kultura w świecie antropologii współczesnej. Próba interpretacji kerygmatycznej, Lublin 2011.

Regiewicz A., Kerygmatyczne czytanie Dekalogu, [w:] A. Regiewicz, Poza horyzontem. Eseje o sztuce czytania, Kraków 2015.

Sobolewski T., Trzy kropki, utrata orientacji, http://wyborcza.pl/piatekekstra/1,130894, 13365730,Trzy_kropki_utrata_orientacji.html.

Sobolewski T., To piękno trzeba złamać, http://wyborcza.pl/piatekekstra/1,130894, 13365759,Szumowska_To_piekno_trzeba_zlamac.html. 